Indanesian Journal of School Counseling: Theory. Application and Development

Volume I Nomar I Tahun 2021. Pages II-20

p-ISSN: 2775-1708 \& e-ISSN: 2775-555X

Homepage: https://ojs.unm..ac.id/ijosc

DDI: https://dai.org/l0.26858/ijosc.vli.l.19317

\title{
Pengembangan Aplikasi E-Counseling Sebagai Upaya Meningkatkan Pemberian Layanan Bimbingan dan Konseling
}

\author{
Muhammad Nazri Jalil \\ Bimbingan dan Kanseling, Fakultas Ilmu Pendidikan, Univeersitas Negeri Makassar \\ Email: muhammadnazrijalill606国gmail.com
}

\section{Abstract}

This study develops an e-counseling application as an effort to improve the provision of guidance and counseling services at Senior High School 1 Jeneponto. The purpose of this study is to determine: (1) Knowing the field needs of the e-counseling application (2) Knowing the prototype of the e-counseling application as an effort to improve the provision of guidance and counseling services at Senior High School 1 Jeneponto, (3) Knowing the validity of the e-counseling application. as an effort to improve the provision of guidance and counseling services at Senior High School 1 Jeneponto. This study used the Borg and Gall Research and Development (RnD) method but only reached the Second Revision stage. This research was conducted at Senior High School 1 Jeneponto with 6 students as research subjects. The data collection technique used was the Material and Media Expert Validation Sheet to determine the validity of the media and the student response questionnaire. The analysis technique used is descriptive analysis technique. So the results show that the ecounseling application developed has been valid and practically used for the provision of guidance and counseling services at Senior High School 1 Jeneponto.

Keywards: E-Counseling Application, Android

\section{Abstrak}

Penelitian ini mengembangkan aplikasi e-counseling sebagai upaya Meningkatkan Pemberian Layanan Bimbingan Dan Konseling di SMA Negeri 1 Jeneponto. Tujuan Penelitian ini adalah untuk mengetahui: (1) Mengetahui kebutuhan lapangan terhadap aplikasi e-counseling (2) Mengetahui Prototipe aplikasi e-counseling sebagai upaya meningkatkan pemberian layanan bimbingan dan konseling di SMA Negeri 1 Jeneponto, (3) Mengetahui Validitas aplikasi e-counseling sebagai upaya meningkatkan pemberian layanan bimbingan dan konseling di SMA Negeri 1 Jeneponto. Penelitian ini menggnakan metode Research and Development (RnD) Borg and Gall namun hanya sampai pada tahapan Revisi II. Penelitian ini dilakukan di SMA Negeri 1 Jeneponto dengan subjek penelitian 6 siswa. Teknik pengumpulan data yang digunakan yaitu Lembar Validasi Ahli Materi dan Media untuk mengetahui validitas media dan Angket Respon siswa.. Teknik analisis yang digunakan adalah teknik analisis deskriptif. Jadi Hasil penelitian menunjukkan aplikasi e-counseling 


\section{IJOSC \\ Indanesian Journal of School Counseling: Theory, Application and Development \\ Volume I Nomor I Tahun 2021. Pages II-ZO \\ p-ISSN: 2775-1708 \& e-ISSN: 2775-555X \\ Homepage: https://ojs.unm.ac.id/ijosc \\ DDI: https://dai.org/I0.26858/ijosc.vlil.19317}

yang dikembangkan telah valid dan praktis digunakan untuk pemberian layanan bimbingan dan konseling di SMA Negeri 1 Jeneponto.

\section{Kata Kunci: Aplikasi E-Counseling, Android}

(c) (1) () This is an open access article distributed under the Creative Commons Attribution License

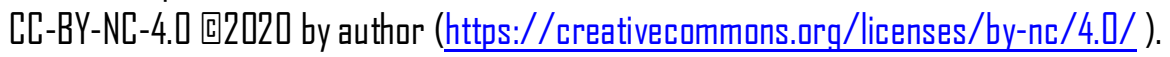

\section{Penuahuluan}

(Received. November-2020; Reviewed: February-2021; Accepted: Maret-2021;

Available anline: April-2021; Published: April-2021)

Perkembangan ilmu pengetahuan dan teknologi merupakan perwujudan perubahan kearah pasitif budaya yang dimiliki manusia. ini dapat dilihat bahwa setiap hasil dari daya yang dimiliki manusia baik cipta, rasa, karsa dan karya yang dikatakan sebagai budaya dalam wujud teknologi dapat meningkatkan produktifitas kerja manusia. dikatakan seperti karena adanya teknologi sedianya akan mempermudah juga meningkatkan efektifitas manusia, sehingga menjadi manusia yang produktif dalam bekerja. Teknologi juga merupakan hasil budaya manusia karena merupakan hasil dari gagasan manusia yang akhirnya melahirkan sebuah karya dan dapat menunjang kehidupan.

Salah satu bidang yang saat ini sedang giat menempatkan teknologi sebagai bagian yang sangat pen ting dalam prosesnya adalah bidang pendidikan. Pendidikan merupakan bidang yang mencoba meningkatkan peran teknologi sebagai salah satu penunjang proses peningkatan efektifitas hasil kerja melalui optimalisasi seraan peserta didik terhadap materi pembelajaran dan pendidikan. Sejalan dengan itu pendidikan di abad 21, peserta didik diharuskan memiliki keterampilan literasi digital. Gilster (2012) mengemukakan bahwa literasi digital adalah kemampuan menggunakan teknologi dan informasi dari piranti digital secara efektif dan efisien dalam berbagai knnteks seperti akademik, karier dan kehidupan sehari-hari. Keterampilan ini menjadi karakteristik siswa di abad 21 yang akrab dengan teknologi.

Bimbingan dan konseling sebagai bagian integral pendidikan juga tak luput dari sentuhan-sentuhan teknolagi dalam pelaksanaannya. Ini juga semakin ditegaskan peranan bimbingan dan konseling dalam UU №. 20 Tahun 2003 Tentang Sistem Pendidikan Nasional. Sehingga dalam hal ini diharapkan proses pemberian layanan bimbingan dan konseling dapat memandirikan peserta didik secara optimal dapat tercapai dengan menggunakan alat bantu maupun layanan-layanan yang berbasis penggunaan teknologi informasi.

Bimbingan dan konseling merupakan kegiatan yang bersumber pada kehidupan manusia. kondisi di lapangan menunjukkan bahwa tidak sedikit peserta didik yang mengalami masalah-masalah baik itu di lingkungan sekolah ataupun di luar lingkungan sekalah. Keberadaan peserta didik tidak sama satu dengan yang lainnya, ada yang bisa mengatasi permasalahannya sendiri dan tidak sedikit yang membutuhkan bantuan konselor. Petrus (20I6) mengemukakan bahwa Konseling merupakan suatu cara profesional untuk membantu orang lain yang berfokus pada kebutuhan dan tujuannya. Сara profesional dapat diartikan sebagai praktik konseling yang melibatkan penggunaan keterampilan-keterampilan spesifik untuk mencapai tujuan bersama konseli. Dengan kata lain konseling adalah seni mempengaruhi konseli. Artinya, proses konseling konseli dapat dipengaruhi secara positif dalam memandang dan bertindak terhadap masalah yang sementara dihadapi sehingga proses perubahan diri konseli dapat berlangsung secara wajar.

Berdasarkan wawancara dengan guru BK dan beberapa orang siswa diketahui bahwa terjadi beberapa permasalahan atau konflik-knnflik yang sering dihadapi oleh siswa itu sendiri, baik permasalahan pribadi hingga 
belajarnya. Dalam wawancara dengan guru BK, bahwa permasalahan yang dihadapi guru BK saat ini adalah banyak siswa yang tidak terbuka dalam menyampaikan permasalahan karena faktor kamunikasi, siswa masih takut berhadapan dengan guru BK secara face to face, masalah yang sangat pribadi (ргivacy) yang sulit untuk disampaikan, juga kurang efektifnya pemberian layanan bimbingan dan konseling membuat siswa tidak dapat menyelesaikan permasalahannya secara mandiri sehingga menurut guru BK diperlukan upaya pemberian layanan bimbingan dan konseling yang efe ktif agar dapat membantu siswa dalam mengentaskan masalah yang dihadapinya.

Dapat disadari bahwa proses konseling menjadi solusi yang sangat efektif dalam upaya menyelesaikan masalah konseli. Namun minimnya pemberian layanan bimbingan dan konseling oleh guru BK di sekolah membuat pemberian layanan bimbingan dan knnseling di sekolah tidak berjalan dengan maksimal, guru BK di sekolah hanya bertugas menertibkan siswa yang melanggar aturan sehingga membuat peran dan fungsi guru BK yang seharusnya menjadi searang sahabat siswa menjadi musuh siswa.

Hasil penelitian yang dilakukan oleh Alwi (2019) menunjukkan bahwa guru BK dan siswa memiliki kebutuhan yang sangat tinggi terhadap prablem bax e-caunseling berbasis aplikasi andraid sebagai media pengungkapan masalah siswa di sekolah dan menunjukkan bahwa aplikasi prablem bax e-caunseling berbasis android dapat diterima dan digunakan dalam implementasi layanan konseling individu online untuk siswa dan guru BK di SMA Islam Athirah I Makassar. Maka peneliti berupaya untuk mengembangkan Aplikasi E-Caunseling (Elektronik Kanseling) berbasis andraid sebagai media penghubung guru BK dengan siswa dalam memberikan layanan bimbingan dan konseling. Sejalan dengan hasil penelitian tersebut maka peneliti berusaha mengembangkan aplikasi e-caunseling sebagai upaya meningkatkan pemberian layanan bimbingan dan knnseling agar dapat membantu siswa dan guru BK dalam melakukan proses knnseling secara jarak jauh dan efektif.

Menurut Amani (2017) E-counseling adalah konseling yang dilakukan melalui akses internet yang secara umum merujuk pada profesi yang berkaitan dengan layanan kesehatan mental melalui teknologi komunikasi internet. Jadi $E$ Caunseling merupakan proses pemberian bantuan yang dilakukan oleh searang professional (konselor) kepada individu yang mengalami masalah (konseli) dalam bentuk media elektronik, media sasial, dan media informasi lainnya yang terhubung dalam internet. E-Caunseling bukan hanya berupa pemberian layanan konseling saja, namun diperluas menjadi penyelenggaraan Bimbingan dan Konseling secara keseluruhan dengan bantuan teknolagi. Tidak hanya online konseling melalui internet namun juga semua aspek pemanfaatan program pengolahan instrument, pengolahan data siswa, aplikasi manajemen konseling, pemanfaatan media saat pemberian layanan klasikal di kelas dan sebagainya termasuk juga pemanfaatan telepon untuk penyelenggaraan konseling.

Aplikasi E-Caunseling ini sebagai strategi upaya meningkatkan pemberian layanan bimbingan kanseling kepada siswa. Dalam pengembangan aplikasi E-Caunseling ini diharapkan dapat menjadi penunjang proses konseling yang dilakukan oleh konselor yang ada di SMA NEGERI I JENEPONTD. Dalam upaya pengembangan aplikasi E-Caunseling ini penulis mengupayakan tetap menggunakan kode etik profesi konselor dalam pengembangannya agar dapat sesuai dengan jalur hukum dan kode etik profesi konselor seperti asas keterbukaan, dan asas kerahasiaan agar dalam pengembangan dan pelaksanaannya dapat berjalan dengan baik sebagaimana mestinya.

Pengembangan aplikasi E-Caunseling ini diharapkan mampu menjawab setiap masalah yang dihadapi oleh konseli dan dapat menjadi tolok ukur konselor dalam analisis masalah konseli agar dalam pemberian layanan konseling dapat berjalan sebagaimana mestinya. Konseli diharapkan secara terbuka mengungkapkan masalahnya dalam E-Caunseling nantinya.

Berdasarkan latar belakang di atas, adapun rumusan masalahnya yaitu :

1) Bagaimana kebutuhan lapangan terhadap aplikasi $e$-counseling?

2) Bagaimana prototipe aplikasi e-counseling sebagai upaya meningkatkan pemberian layanan bimbingan dan konseling di SMA Negeri I Jeneponto 
3) Bagaimana tingat validitas dn kepraktisan aplikasi e-counseling sebagai upaya meningkatkan pemberian layanan bimbingan dan konseling di SMA Negeri I Jeneponto.

\section{METDDE}

Penelitian dan pengembangan Aplikasi E-Caunseling sebagai upaya meningkatkan pemberian layanan bimbingan dan konseling di SMA NEGERI I JENEPONTO ini dilakukan dengan menggunakan pendekatan penelitian dan pengembangan (Research and Depelapment) Barg and Gall. Menurut Sugiyono (2012: 407) metade penelitian dan pengembangan atau dalam bahasa Inggrisnya Research and Deve/opment adalah metade penelitian yang digunakan untuk menghasilkan produk tertentu dan menguji keefektifan produk tersebut. Untuk dapat menghasilkan produk tertentu digunakan penelitian yang bersifat analisis kebutuhan dan untuk menguji

Keefektifan produk supaya dapat berfungsi di masyarakat luas, maka diperlukan penelitian untuk menguji keefektifan produk tersebut. Jadi penelitian pengembangan bersifat longitudinal (bertahap bisa multy years).

Menurut Barg and Gall (2003: 782) yang dimaksud dengan model penelitian pengembangan adalah "a pracess used develap and validate educationa/ praduct".Penelitian pengembangan muncul sebagai strategi yang bertujuan untuk meningkatkan kualitas pendidikan, mengembangkan dan memvalidasi hasil-hasil pendidikan. Dalam penelitian Research and Develapment ini digunakan untuk menghasilkan Aplikasi E-Caunseling sebagai upaya meningkatkan pemberian layanan bimbingan dan knnseling di SMA NEGERI I JENEPONTD.

Penelitian dengan pendekatan pengembangan dilaksanakan melalui tahapan- tahapan yang saling berkaitan. Model pengembangan madul ini mengacu pada strategi pengembangan yang dikemukakan oleh Barg and Gall (2003: 150). Strategi ini disebut penelitian dan pengembangan (Research and Development). Penelitian dan pengembangan merupakan siklus pengembangan yang terdiri dari I0 langkah pengembangan yaitu :

I. Penelitian awal dan pengumpulan informasi awal

2.Perencanaan pengembangan

3.Pengembangan format produk awal

4. Lji coba awal

5.Revisi produk I

6.Uji coba lapangan

7. Revisi produk II

8. Uji coba lapangan

9.Revisi produk akhir

10. Deseminasi dan Implementasi

Agar pengembangan aplikasi ini mengacu pada langkah-langkah pengembangan di atas, maka peneliti memodifikasi langkah-langkah pengembangan yang dilaksanakan sebagai berikut:

1. Analisis kebutuhan dan pengumpulan informasi, mengidentifikasi kebutuhan subyek tentang produk yang akan dikembangkan dan mengumpulkan informasi tentang fenomena masalah antarsiswa di sekolah, studi literatur. perumusan masalah.

2. Perencanaan dan pengembangan, merumuskan tujuan pengembangan dan menentukan materi yang akan dikembangkan.

3. Pengembangan produk awal, desain produk, pembuatan produk.

4. Uji ahli (validasi ahli)

5. Revisil

6. Uji kelompok kecil 
7. Revisi II

8. Uji kelompok terbatas (produk akhir).

Tempat Penelitian pengembangan ini dilaksanakan di SMA NEGERI I JENEPONTQ, dipilihnya tempat ini karena masih banyaknya permasalahan-permaslahan yang dihadapi oleh siswa yang membutuhkan penanganan serius dengan menggunakan konseling, hadirnya aplikasi e-konselig sebagai upaya untuk mengentaskan masalah yang ada pada diri knnseli itu sendiri secara lebih efektif dan efisien, baik dalam bentuk dan penggunaannya konselor akan dimudahkan dengan adanya aplikasi e-konseling ini.

Untuk memperuleh data yang diperlukan dalam pengembangan Aplikasi E-Caunseling digunakan dua teknik pengambilan data yaitu wawancara, angket, dan observasi.

a. Wawancara

Menurut Esterberg (Sugiyono, 2012: 72), interviu atau wawancara adalah merupakan pertemuan dua arang untuk bertukar infarmasi dan ide melalui tanya jawab, sehingga dapat dikanstruksikan makna dalam suatu topik tertentu.Arikunto (2002, 132), interviu sering juga disebut dengan wawancara atau kuesioner lisan, adalah sebuah dialog yang dilakukan pewawancara untuk memperoleh informasi dari terwawancara.

Menurut Sugiyano (20IZ: 72), wawancara digunakan sebagai teknik pengumpulan data apabila peneliti ingin melakukan studi pendahuluan untuk menemukan permasalahan yang harus diteliti, tetapi juga apabila peneliti ingin mengetahui hal-hal dari responden yang lebih mendalam. Pengumpulan data dengan cara wawancara dilakukan untuk mengumpulkan data berupa tanggapan atau penilaian dari para ahli pada madul bimbingan pribadi sasial yang dikembangkan. Proses wawancara melalui wawancara bebas terpimpin yaitu dengan membuat garis-garis besar infarmasi yang ingin didapat. Masing-masing ahli mengevaluasi berdasarkan bidang keahlian masing-masing. b.Angket

Menurut Sugiyano (2012: 199) angket atau kuesionar merupakan teknik pengumpulan data yang dilakukan dengan cara memberi seperangkat atau pernyataan tertulis kepada responden untuk dijawabnya.

Arikunto (200Z: 140) menjelaskan bahwa angket adalah seperangkat pertanyaan tertulis yang ditujukan kepada responden untuk mengungkap pendapat, keadaan, dan kesan yang ada pada responden sendiri maupun luar dirinya. Hadi (2002: 157) mengemukakan alasan pemilihan angket adalah berdasarkan asumsi sebagai berikut:

1. Bahwa subyek adalah orang yang paling tahu tentang dirinya.

2. Bahwa apa yang dinyatakan oleh subyek kepada penyidik adalah benar dan dapat dipercaya.

3. Bahwa interpretasi subyek tentang pertanyaan-pertanyaan yang diajukan kepadanya adalah sama dengan apa yang dimaksudkan oleh peneliti.

Alat pengumpul data berupa angket ini digunakan untuk mengumpulkan data berupa tanggapan atau penilaian siswa SMA NEGERI I JENEPTNTC terhadap Aplikasi E-Caunseling yang akan dikembangkan. Bentuk angket yang digunakan oleh peneliti adalah gabungan bentuk angket tertutup dengan pilihan jawaban berupa pernyataan. Setiap pernyataan memiliki alternatif jawaban yang skalanya 1-4 Skala I menunjukkan penilaian sangat rendah dan skala 4 menunjukkan penilaian-penilaian yang sangat tinggi. Selain itu terdapat butir pertanyaan dalam butir angket yang menghendaki subyek untuk menuliskan komentar mengenai komponen kegiatan tersebut.Data yang diperoleh dari angket adalah data kuantitatif dan kualitatif.

c. Tbservasi

Menurut Sutrisno Hadi (1989) observasi merupakan suatu proses yang kompleks, suatu proses yang tersusun dari berbagai proses biologis dan psikologis. Dua diantara yang terpenting adalah proses-proses pengamatan dan ingatan. Dari segi instrumentasi yang digunakan, maka observasi dapat dibedakan menjadi observasi terstruktur dan tidak terstruktur.

Observasi terstruktur adalah observasi yang telah dirancang secara sistematis, tentang apa yang akan diamati, kapan dan di mana tempatnya. Jadi observasi terstruktur dilakukan apabila peneliti telah tahu dengan pasti 
tentang variabel apa yang akan diamati. Dalam melakukan pengamatan peneliti menggunakan intrumen penelitian yang telah teruji validitas dan reabilitasnya. Maka peneliti dapat menilai setiap perilaku dan ucapan dengan menggunakan instrumen yang digunakan. Sedangkan, observasi tidak terstruktur adalah observasi yang tidak dipersiapkan secara sistematis tentang apa yang akan diobservasi. Hal ini dilakukan karena peneliti tidak tahu secara pasti tentang apa yang akan diamati. Dalam melakukan pengamatan peneliti tidak menggunakan intrumen yang telah baku, tetapi hanya berupa rambu-rambu pengamatan.

Adapun teknik analisis data yang digunakan untuk mengulah data yang diperoleh dalam pengembangan aplikasi e-counseling sebagai upaya meningkatkan pemberian layanan bimbingan dan konseling di SMA Negeri I Jeneponto adalah dengan menggunakan analisis deskriptif

Analisis deskriptif digunakan untuk menganalisis data kuantitatif yang diperoleh dari angket lembar evaluasi uji coba kelompok. Menurut Arikunto (2002: 246) data kuantitatif yang berupa angka-angka hasil perhitungan atau pengukuran dapat diproses dengan cara:

dijumlah, dibandingkan dengan jumlah yang diharapkan dan diperoleh persentase. Kadang-kadang pencarian persentase dimaksudkan untuk mengetahui status sesuatu yang dipersentasekan dan disajikan tetap berupa persentase. Sesudah sampai kepersentase lalu ditafsirkan dengan kalimat yang bersifat kualitatif, misalnya sangat valid (76\%-100\%), valid (56\%-75\%), kurang valid (40\%-55\%) tidak valid (kurang dari 40\%).

Jawaban yang diperoleh melalui angket dijumlahkan atau dikelompokkan sesuai dengan bentuk instrumen yang digunakan (Arikunto.2002: 213). Angket yang digunakan dalam penelitian ini adalah angket dengan bentuk jawaban sesuai dan tidak sesuai, maka sebelum dilakukan analisa, peneliti menjumlahkan seberapa banyak jawaban sesuai dan seberapa banyak jawaban tidak sesuai, kemudian peneliti mempersentasekan dengan menggunakan rumus berikut ini:

$$
\begin{aligned}
& \mathrm{p}=\frac{\Sigma \mathrm{x}}{\Sigma \mathrm{y}} 100 \\
& \text { Keterangan : } \mathrm{P}=\text { Persentase } \\
& \qquad \begin{array}{l}
\Sigma \mathrm{x}=\text { Jumlah skar yang diperoleh } \\
\sum \mathrm{y}=\text { Jumlah skar maksimal }
\end{array}
\end{aligned}
$$

Setelah diperoleh persentase dengan rumus tersebut di atas, kemudian peneliti menafsirkan hasil pers entase tersebut ke dalam lima kriteria kevalidan yaitu: sangat tinggi, sesuai, cukup sesuai, tidak sesuai, dan sangat tidak sesuai.

\begin{tabular}{|c|c|}
\hline Nilai Rata-rata & Kriteria Kevalidan \\
\hline $81 \%-100 \%$ & Sangat tinggi \\
\hline $61 \%-80 \%$ & Tinggi \\
\hline $41 \%-60 \%$ & Sedang \\
\hline $21 \%-40 \%$ & Rendah \\
\hline $5 \%-20 \%$ & Sangat Rendah \\
\hline
\end{tabular}

\section{HASIL DAN PEMBAHASAN}

\section{Hasil}

Analaisis kebutuhan tidak hanya didasarkan pada asumsi-asumsi dalam menganalisis kebutuhan saja tetapi didasarkan juga pada hasil studi pendahuluan yang dilakukan oleh peneliti dengan menggunakan teknik survei melalui wawancara (interview) dengan guru pembimbing dan siswa di SMA Negeri I Jenepanto.

Dari hasil survei melalui wawancara kepada seorang guru pembimbing di sekolah tersebut, diperaleh informasi-informasi bahwa terjadi beberapa permasalahan atau knnflik-konflik yang dihadapi siswa baik permasalahan 
pribadi hingga belajarnya namun dalam pemberian layanan bimbingan dan konseling masih belum dilakukan secara maksimal dikarenakan belum adanya jam khusus bagi guru pembimbing dalam memberikan bimbingan kepada siswa ditambah lagi dengan kurangnya sosialisasi mengenai peran guru pembimbing dalam pemberian layanan bimbingan dan knnseling kepada siswa, hal tersebut menyebabkan siswa tidak dapat menyelesaikan masalahnya secara mandiri dan malu juga ragu untuk berkunjung ke ruangan BK untuk menceritakan masalahnya kepada guru pembimbing. Sehingga menurut guru pembimbing sangat perlu dan penting untuk membuat inavasi dalam pemberian layanan bimbingan dan konseling yang baru dan menarik untuk siswa, maka dalam hal ini aplikasi e-counseling.

Dari hasil survei tersebut, proses pemberian layanan bimbingan dan konseling kemudian dievaluasi dan dikembangkan pengembangan aplikasi e-caunseling yang didasarkan dengan kebutuhan-kebutuhan guru pembimbing dan siswa. Aplikasi ini diimplementasikan untuk membantu siswa dan guru pembimbing.

Perencanaan pengembangan yang dimaksudkan merupakan hal-hal yang dipersiapkan untuk membuat aplikasi e-counseling yaitu :

a) Perancangan aplikasi

Perancangan aplikasi ini dilakukan dengan mempertimbangkan kebutuhan-kebutuhan siswa dan guru pembimbing dengan memuat beberapa fitur dalam aplikasinya. Seperti kebutuhan dalam pemberian layanan konseling individu dan konseling kelompok anline.

b) Tenaga yang dipersiapkan

Penelitian ini dilakukan langsung oleh peneliti yaitu sebagai fasilitatar dan teman peneliti yang membantu mempersiapkan sarana dan prasarana yang akan digunakan

c) Media yang digunakan

Dalam pembuatan aplikasi e-caunseling ini, peneliti menggunakan website kodular.io dalam pembuatan aplikasi ini dengan menggunakan sistem android pada smartphone.

Berdasarkan hasil dari uji validasi data kualitatif oleh ahli materi dan ahli media dan desain pembelajaran dapat disimpulkan bahwa aplikasi e-counseling sudah sesuai dengan kebutuhan Guru BK dan siswa sebagai media atau alat komunikasi dalam pemberian layanan bimbingan dan konseling dan layak untuk digunakan dalam penelitian dan layak untuk uji coba layanan setelah melakukan revisi, juga berdasarkan hasil dari uji validasi data kualitatif oleh ahli teknologi informasi dapat disimpulkan bahwa aplikasi e-caunseling ini menarik dan layak untuk uji kelompok kecil setelah melakukan revisi terlebi dahulu.

Adapun hasil uji coba kelompok kecil yang diberikan kepada 6 orang siswa SMA Negeri I Jeneponto sebagi berikut:

\begin{tabular}{llc}
\hline Pertanyaan & Jawaban & \\
\cline { 2 - 3 } & & \\
& & \\
\hline Apakah aplikasi e-counseling ini sangat menarik? & $\mathbf{1 0 0 \%}$ & $\mathbf{0 \%}$ \\
\hline Apakah aplikasi $e$-caunseling ini praktis digunakan? & $\mathbf{8 3 \%}$ & $\mathbf{1 7 \%}$ \\
\hline
\end{tabular}




\begin{tabular}{|c|c|}
\hline $\begin{array}{l}\text { Apakah aplikasi } e \text {-counseling ini menggunakan bahasa 100\% } \\
\text { yang sederhana dan mudah dipahami? }\end{array}$ & Q\% \\
\hline $\begin{array}{l}\text { Apakah pengoperasian aplikasi } \varepsilon \text {-counseling ini mudah } 83 \% \\
\text { dipahami? }\end{array}$ & $17 \%$ \\
\hline $\begin{array}{l}\text { Apakah aplikasi e-counseling ini membantu anda } 100 \% \\
\text { berkomunikasi dengan guru BK? }\end{array}$ & प\% \\
\hline $\begin{array}{l}\text { Apakah aplikasi } e \text {-counseling ini menyulitkan anda untuk } 33 \% \\
\text { mengungkapkan masalah anda pada guru BK? }\end{array}$ & $67 \%$ \\
\hline $\begin{array}{l}\text { Apakah anda tidak menyukai tampilan aplikasi } \quad E-33 \% \\
\text { caunseling ini? }\end{array}$ & $67 \%$ \\
\hline Apakah anda membutthkan aplikasi $e$-counseling ini? $\quad 83 \%$ & $17 \%$ \\
\hline
\end{tabular}

\section{Pembahasan}

Berdasarkan hasil informasi dan analisis kebutuhan yang diperoleh dari siswa dan guru BK di sekolah, hasil kajian teoritis dan empirik sangatlah diperlukan hadirnya pemberian layanan bimbingan dan konseling yang menarik dan inovatif guna membantu siswa dalam pengentasan masalahnya. Sejalan dengan analisis kebutuhan telah dilakukan melalui pengumpulan infarmasi, sebelum melakukan pengembangan aplikasi $e$-Counseling dilakukan studi literatur mengenai $e$-counseling. Studi literatur dan need assesment untuk mengetahui kebutuhan guru BK di sekolah mengenai area implementasi model pengembangan.

Pengembangan aplikasi $e$-counseling merujuk pada need assesment dan asumsi bahwa dalam perkembangan penyelenggaraan knnseling yang tadinya dilakukan secara tatap muka (face to face) dalam ruang tertutup, bisa dilakukan secara jarak jauh dengan dukungan teknologi infarmasi yang selanjutnya dikenal dengan istilah $e$-counseling. Di Indonesia sendiri tidak ada informasi yang pasti tentang istilah e-konseling. Pada tahun 2009 IFDIL secara khusus memperkenalkan istilah penayaan $e$-counseling di Indanesia, pelayanan $e$-conseling diperluas menjadi pelayanan penyelenggaraan bimbingan dan konseling (BK) secara keseluruhan dengan bantuan teknologi. Maka pengembangan aplikasi e-counseling ini diangap penting sebagai inovasi dalam pemberian layanan bimbingan dan konseling di sekolah.

\section{SIMPULAN DAN SARAN}

Berdasarkan hasil dan pembahasan hasil penelitian serta tahap pengembangan aplikasi $e$-caunseling, dapat ditarik kesimpulan bahwa Guru BK dan siswa di sekolah menunjukkan kebutuhan yang tinggi akan adanya aplikasi $\varepsilon$ counseling sebagai upaya meningkatkan pemberian layanan bimbingan dan konseling di SMA Negeri I Jeneponto. Protatipe aplikasi $e$-counseling terdiri dari 2 aplikasi yaitu aplikasi $e$-counseling bagi Guru BK dan aplikasi $e$-counseling bagi siswa, namun dapat terhubung secara langsung dalam keadaan daring, Tingkat validitas aplikasi e-counseling berada pada kategori tinggi, sementara tingkat kepraktisannya berada pada kategori sangat tinggi. Dengan demikian, disimpulkan bahwa aplikasi $e$-Counseling valid dan praktis untuk digunakan di sekolah sebagai alat atau media komunikasi guru BK dan siswa secara daring dalam meningkatkan pemberian layanan bimbingan dan konseling.

Berdasarkan hasil penelitian yang telah dilakukan dan dinyatakan layak untuk digunakan dan memberikan implikasi kepada berbagai pihak sehingga direkomendasikan terhadap pengembangan ilmu pengetahuan, pemecahan masalah pendidikan, pengembangan kelembagaan dan penelitian lebih lanjut. Pengembangan ilmu pengetahuan, hasil penelitian ini menunjukkan aplikasi $e$-counseling, baik dari segi konseptual maupun dari segi praktis memiliki kelayakan untuk digunakan di sekolah. Dari segi pengembangan ilmu teknologi, aplikasi ini dapat memberikan kontribusi bagi pengembangan ilmu bimbingan kanseling. Juga sebagai pemecahan masalah pendidikan, aplikasi $e$-counseling ini 
Indonesian Journal of School Counseling: Theory, Application and Development Volume I Nomor I Tahun 2021. Pages II-20 p-ISSN: 2775-1708 \& e-ISSN: 2775-555X

Homepage: https://ojs.unm.ac.id/ijosc

DDI: https://dai.org/I0.26858/ijosc.vlil.19317

didasarkan atas kebutuhan akan adanya suatu inovasi yang dapat digunakan oleh guru BK dalam membantu mengatasi permasalahan siswa di seknlah, terutama bagi siswa yang memiliki permasalahan pribadi sasial dalam hubungan dengan sesama teman dan penyelesaian konflik. Berdasarkan pertimbangan kebutuhan dan masalah tentang bimbingan konseling tersebut maka hasil penelitian ini direkamendasikan untuk digunakan di sekolah agar dapat membantu guru BK dalam pemberian layanan bimbingan dan konseling di sekolah.

\section{DAFTAR RUJUKAN}

Abimanyu S \& Manrihu T. 2009. Teknik dan Laburatorium Kanseling dilid I. Makassar. Badan Penerbit Universitas Negeri Makassar.

Abidin Zainal. 2009. Dptimalisasi Kanseling Individu dan Kelompok Lntuk Keberhasilan Siswa. Jurnal Pemikiran Alternatif Pendidikan. Vol 14 (1): $132-148$.

Herina \& Khasanah Uswatun. 2019. Membangun Karakter Siswa Melalui Literasi Digital Dalam Menghadapi Pendidikan Abad 21 (Revolusi Industri 4.0). Prosiding Seminar Nasional Pendidikan. Program Pascasarjana Universitas PCRI Palembang. Palembang 12 Januari 2019.

Haryadi, R., Fauziatin \& Kharunisa. 2020. Peran Chat Grup Untuk Mengaptimalkan Bimbingan Dan Kanseling Kelampak Dnline DiAbad 21. Jurnal Mahasiswa BK. Vol. 6 (I) : 13-18

Ifdil \& Ardi Z. 2013. Kanseling Dnline Sebagai Salah Satu Bentuk Pelayanan E-Caunseling. Jurnal Kanseling dan Pendidikan. Vol. I(I) : 15-2I.

Pandang, Aryani dan Alwi. 2019. Pengembangan "Prablem Bax E-Caunseling" Berbasis Andruid Aplikasi Sebagai Media Pengungkapan Masalah Siswa. Jurnal Psiknlogi Pendidikan \& Bimbingan. Vol. 5 (Z) : IIZ-IIY.

Prasetya RY \& Djuniadi. 2015. Implementasi E-Caunseling Pada Sacia/ Learning Netwark. Jurnal Edu Kamputika. Vol 2 (2) $: 9-18$

Prahesti Y \& Wiyono BD. 2017. Pengembangan Website Kanseling Dnline Untuk Siswa di SMA Negeri I Gresik. Jurnal Bimbingan dan Konseling. Vol 7 (3) : 144-154.

Petrus J. 20I6. Kajian Kanseptual Hubungan Terapeutik Dan Faktar - Faktar Yang Mempengaruhi Keberhasilan Prases Kanseling. Pendidikan Bimbingan Konseling Universitas Negeri Semarang. Vol I (2): I-I]

Petrus ل G Sudibyo H. 2017. Kajian Kanseptua/Layanan Cybercounseling. Jurnal Konselor. Vol G (I): 6-12.

Redhana I.W. 2019. Mengembangkan keterampilan abad ke-2/ dalam pembelajaran kimia. Jurnal inavasi Pendidikan Kimia. Vol. 13 (I) : 2239-2253.

Ruhansih DS. 2018. Masalah-masalah siswa di sekalah serta pendekatan-pendekatan umum dalam bimbingan dan kanseling ditinjau dari "kaca mata kanselor" (studi deskriptif di smp nugraha bandung. Jurnal Bimbingan dan Konseling. Vol. 2 (I): I-3. 
Indonesian Journal of School Counseling: Theory, Application and Development Volume I Nomor I Tahun 2021. Pages II-20 p-ISSN: 2775-1708 \& e-ISSN: 2775-555X

Homepage: https://ojs.unm.ac.id/ijosc DDI: https://dai.org/10.26058/ijosc.vlil.19317

Sirajuddin KH. 2017. Implementasi protatype aplikasi e-kanseling untuk menunjang pelayanan kanseling berbasis jejaring sasial. Indanesian لaurnal on Information System. Vol. I (2): $48-56$

Sumarwiyah \& Zamroni E. 2017. Pemanfaatan Teknologi Infamasi (TI) Dalam Layanan Bimbingan dan Kansaling Sebagai Representasi Berkembangnya Budaya Profesional Kanse/or Dalam Melayani Siswa. Jurnal Bimbingan dan Konseling. Vol 2 (I) : 1-14. 